DOI https://doi.org/10.36059/978-966-397-244-2-2-2

\author{
Дрозд О. Ю. \\ доктор юридичних наук, професор, \\ в.о. начальника відділу докторантури та ад'юнктури \\ Національна академія внутрішніх справ \\ м. Київ, Україна
}

\title{
ЦИВІЛЬНО-ПРАВОВЕ РЕГУЛЮВАННЯ ШТУЧНОГО ІНТЕЛЕКТУ
}

Робота присвячена дослідженню цивільно-правового регулювання відносин із використання штучного інтелекту. Оскільки науково-технічний прогрес та поява нових технологій постійно супроводжуються розробкою інноваційних проектів та продуктів, це призводить до появи прогалин та колізій у законодавстві. Основною проблемою є відсутність спеціальних міжнародних та національних норм, які б регламентували правовий статус штучного інтелекту у цивільно-правових відносинах. у рамках статті автор досліджує історію становлення, поняття та ознаки штучного інтелекту. Проаналізовано міжнародні акти, які регламентують окремі питання щодо ролі штучного інтелект у цивільно-правових відносинах. Зазначено, що на сьогодні вчені не дійшли консенсусу щодо правового статусу цього феномену. Доведено, що з метою подальшого розвитку штучного інтелекту та можливості його використання у всіх сферах суспільної діяльності необхідно чітко визначити питання регламентації вказаних відносин.

\section{Вступ}

Ідея створення людиноподібних мислячих машин походить здавна. Ще в Давньому Єгипті простий люд відчував страх і благоговіння перед особливими культовими фігурами, здатними здійснювати рухи і пророкувати. Природно, що всі ці пристрої управлялися безпосередньо самою людиною. У Середньовіччі, відомому своєю забороненою церквою пристрастю до природних і технічних дисциплін і експериментів, були створені більш складні людиноподібні конструкції, що приводилися в рух шляхом взаємодії різних механізмів. У Новий час, завдяки бурхливому розвитку техніки, подібні ідеї стали ще більш 
популярними. Французький винахідник Жак де Вокансон виготовив механічного флейтиста людського зросту, який виконував дванадцять мелодій, перебираючи пальцями отвори і дуючи в мундштук як справжній музикант [1, с. 125].

У світлі активного розвитку інформаційних технологій дискусії з приводу штучного інтелекту набирають усе більших обертів. Нові можливості, які відкриваються у цій сфері (робота з великими обсягами даних, машинне навчання, інструменти віртуальної та доповненої реальності), також піднімають i питання ризиків, які вони створюють для суспільства і життя людей в цілому.

Зростаюче використання штучного інтелекту зумовлює необхідність визначення його правового статусу та внесення відповідних змін до чинних законодавчих актів, адже наразі в Україні відсутнє нормативне регулювання цього питання.

\section{1. Поняття, ознаки та різновиди штучного інтелекту}

Штучний інтелект (англ. Artificial intelligence, AI) - це широка галузь комп'ютерних наук, які спрямовані на імітацію інтелекту людини машинами. I хоча активні обговорення цієї технології почалися на початку 2000-х, вона далеко не нова. Термін «штучний інтелект» ввів до наукового обігу професор Дартмутського коледжу Джон МакКарті ще у 1956 році, коли очолив невелику команду вчених, аби визначити, чи $є$ у машин здатність до навчання та формального мислення [2, с. 130-131].

Технологічними передумовами до виникнення штучного інтелекту стало створення у 1623 році Вільгельм Шикардом першої механічної цифрової обчислювальної машини; згодом такі ж машини були побудовані Блезом Паскалем і Лейбніцом. Останній також описав сучасну двійкову 177 систему числення $[3$, c. 23].

У середині 1750-х років австрієць Фрідріх фон Кнаус, який служив при дворі Франциска I, сконструював серію машин, які вміли тримати перо і могли писати досить довгі тексти. Інший майстер - П’єр Жак-Дроз зі Швейцарії - побудував пару складних механічних ляльок: хлопчика, що пише листи, і дівчину, що грає на клавесині. У 1830-х роках англійський математик Чарльз Беббідж задумав (однак не завершив) складний цифровий калькулятор, який він назвав аналітичною машиною; за 
твердженням Беббіджа, його машина могла б розраховувати ходи під час гри у шахи [4, с. 40].

Пізніше, в 1914 р., директор одного з іспанських технічних інститутів Леонардо Торрес-і-Кеведо дійсно виготовив електромеханічний пристрій, здатний розігрувати найпростіші шахові партії майже так само добре як і людина. Компактний механічний арифмометр, сконструйований на початку XX ст. став дуже популярним серед інженерних працівників, економістів, учителів і протримався в експлуатації аж до кінця XX ст. [4, с. 41].

У XIX ст. на основі алгебри Дж. Буля, яка представляла собою формалізацію арифметичних дій, було запропоновано скористатися алгебраїчною мовою і для формалізації логічного процесу міркування. Були введені символи для всіх можливих логічних констант, що характеризують формальні елементи в судженнях, логічні сполучники; таблиці ж істинності Вітгенштейна завершили процес формалізації мислення. У $30-\mathrm{i}$ pp. XX ст. інформатики (зокрема, американський вчений Клод Шеннон) зрозуміли, що двійкова одиниця і нуль цілком відповідають двом станам електронного ланцюга (включено-виключено), тому двійкова система ідеально підходить для електроннообчислювальних пристроїв [5].

Цей процес електронного обрахування подій має значні наслідки - всі події світу можуть бути формалізовані і піддані електронній обробці. Правда, для цього, за словами філософа Хьюберта Дрейфуса, необхідно спочатку задати відповідну онтологію світу. На думку американського мислителя, зелене світло могутньому розвитку цифрових комп'ютерів дала якраз онтологія логічного атомізму, розвинена на початку XX ст. в аналітичній філософії (Фреге, Рассел, Вітгенштейн) [6].

Якщо уявити весь світ сукупністю простих об’єктів, то технології цифрового «міркування», тобто обробки інформації, охоплять собою не тільки область мислення людини, але і суще в цілому. Хьюберт Дрейфус вважав, що цифрові технології стали настільки популярними саме завдяки «пануванню» цієї онтологічної парадигми у XX ст. [6].

Безпосередньо ж історія штучного інтелекту починається 3 моменту створення перших ЕОМ у 40-х рр. ХХ ст. Саме з їх появою виникло питання: чи можливо створити машину, інтелектуальні можливості якої були б тотожні інтелектуальним можливостям людини (або навіть перевершували їх) [8, с. 60]. 
Наступним етапом в історії штучного інтелекту є 50-і pp. $\mathrm{XX}$ ст., коли дослідники намагались будувати розумні машини взявши за основу роботу мозку людини. Ці спроби виявилися безуспішними з причини повної непридатності як апаратних, так і програмних засобів. У 1956 р. відбувся семінар в Стенфордському університеті (США), де вперше запропоновано термін «штучний інтелект»- artificial intelligence [7, с. 62].

60-і pp. XX ст. відзначилися спробами відшукати загальні методи розв'язання широкого класу задач, моделюючи складний процес мислення. Розробка універсальних програм виявилася занадто важкою і безплідною справою. Чим ширший клас задач, які може вирішувати одна програма, тим слабше проявляються їі можливості при вирішенні конкретної проблеми. У цей період почалося зародження евристичного програмування - розробки стратегії дій за аналогією або прецедентів. Загалом, цей період можна назвати пошуком універсального алгоритму мислення [6].

Істотний прорив відбувся у 70-х pp. XX ст., коли на зміну пошукам універсального алгоритму мислення прийшла ідея моделювати конкретні знання фахівців-експертів. У США з'явилися перші комерційні системи, засновані на знаннях, або експертні системи. Утворився новий підхід до вирішення завдань штучного інтелекту - представлення знань. "MYCIN" і "DENDRAL" стали вже класичними експертними системами в області медицини i хімії. Ïх y певному сенсі можна назвати діагностичними, оскільки "MYCIN" допомагає за певними симптомами (ознаками патології організму) встановити хворобу (поставити діагноз); "DENDRAL" здатна за аналізом низки властивостей визначити хімічну сполуку [4, с. 41].

У 80-і pp. XX ст. штучний інтелект переживає «друге народження». На цьому етапі усвідомлюються його потенційні можливості як у дослідженнях, так і в розвитку виробництва. У рамках нової технології з'явиляються перші комерційні програмні продукти. У цей час починає розвиватися галузь машинного навчання [4, с. 44].

Із тих пір в області штучного інтелекту розроблено безліч комп'ютерних систем, які прийнято називати інтелектуальними. Області їх практичного застосування охоплюють практично всі сфери людської діяльності, пов'язані з обробкою інформації.

Таким чином, існує кілька точок зору у визначенні значення «штучного інтелекту»: 
1. Штучний інтелект як вміння вирішувати складні завдання;

2. Штучний інтелект як здатність до навчання, узагальнення і аналогій;

3. Штучний інтелект як можливість взаємодії із зовнішнім світом шляхом спілкування, сприйняття й усвідомлення сприйнятого [8, с. 194].

Отже, штучний інтелект - властивість автоматичних систем брати на себе окремі функції інтелекту людини, наприклад, приймати оптимальні рішення на основі раніше отриманого досвіду і раціонального аналізу зовнішніх впливів.

Постійні зміни у соціально-правовому житті людей та держав, а також зростаючий інтерес до цього феномену породжує необхідність його правової регламентації, визначення поняття, ознак, видів та інших особливостей. Велика кількість науковців намагається вирішити цю проблему за допомогою наявних у правовій науці категорій та понять, втім на сьогодні ще не розроблено нормативного визначення штучного інтелекту. Натомість інтелект розуміється як «здатність побудови моделі поведінки на основі алгоритму вирішення завдань, сформованого свідомістю; це загальна здатність до пізнання і вирішення проблем, яка об'єднує всі пізнавальні здібності, такі як відчуття, сприйняття, пам'ять, уявлення, мислення, уява» (А. Азімов) [9].

Штучний інтелект визначається як Artificial intelligence (AI) розділ комп'ютерної лінгвістики та інформатики, що опікується формалізацією проблем та завдань, які подібні до дій, що виконує людина; це здатність інженерної системи здобувати, обробляти та застосовувати знання та вміння. Єдиної відповіді на питання, чим опікується штучний інтелект, не існує. Майже кожен автор, який пише книгу про штучний інтелект, відштовхується від якогось визначення та розглядає його у світлі досягнення цієї науки. Зазвичай ці визначення зводяться до таких:

- штучний інтелект вивчає методи розв'язання завдань, які потребують людського розуміння. Отже, йдеться про те, щоби навчити штучний інтелект розв'язувати тести інтелекту. Це передбачає розвиток способів розв'язання задач за аналогією, методів дедукції та індукції;

- штучний інтелект вивчає методи розв'язання задач, для яких не існує способів розв'язання або вони не коректні (через обмеження в часі, пам'яті тощо). Завдяки такому визначенню 
Новітні досягнення та вектори розвитку сучасної юриспруденції

інтелектуальні алгоритми часто використовуються для розв'язання NP-повних задач;

- штучний інтелект займається моделюванням людської вищої нервової діяльності;

- штучний інтелект - це системи, які можуть оперувати зі знаннями, а найголовніше - навчатися. Насамперед йдеться про те, щоби визнати клас експертних систем (назва походить від того, що вони спроможні замінити «на посту» людей-експертів) інтелектуальними системами;

- останній підхід, що розвивається з 1990-х років, називається агентно- орієнтованим підходом. Цей підхід зосереджує увагу на тих методах і алгоритмах, які допоможуть інтелектуальному агенту виживати в довкіллі під час виконання свого завдання [10].

Експерти НАТО у своїй діяльності оперують спорідненими тлумаченнями штучного інтелекту: «спроможність, що надається алгоритмами оптимального або неоптимального вибору 3 широкого простору можливостей, для досягнення цілей шляхом застосування стратегій, які можуть спиратися на навчання або адаптацію до навколишнього середовища»; «системи, які створені людиною і діють у фізичному або цифровому світі, враховують складну мету і обирають найкращі дії (відповідно до заздалегідь визначених параметрів), які необхідно виконати для досягнення поставленої мети на основі сприйняття свого середовища, інтерпретації зібраних структурованих або неструктурованих даних та обгрунтування знань, отриманих із цих даних» [10].

Штучний інтелект - наука та технологія створення інтелектуальних машин (програмних комплексів), здатних брати на себе окремі функції інтелектуальної діяльності людини (наприклад, вибирати та приймати оптимальні рішення на основі раніше отриманого досвіду і раціонального аналізу зовнішніх впливів). За іншим визначенням, під штучним інтелектом розуміється науковий напрям, у межах якого ставляться та вирішуються завдання апаратного або програмного моделювання тих видів людської діяльності, які традиційно вважаються інтелектуальними. Саме у цьому сенсі термін штучного інтелекту ввів Джон Маккарті в 1956 р. на конференції в Дартмунтському університеті [11, с. 165].

До ознак штучного інтелекту наковці відносять: 1) здатність до комплексної обробки значних обсягів інформації, здобутої з 
різних джерел; 2) здатність до самонавчання (в тому числі, накопичування досвіду, узагальнення, відшукування неочевидних зв'язків) та умовиводів; 3) вміння планувати; 4) здатність до роздумів (у відповідь на роздуми розробників про нього, штучний інтелект буде витрачати більш потужні ресурси на роздуми про них [12].

Крім того, у широкому розумінні штучний інтелект може бути наділений такими властивостями:

1) здатність до абстрактного мислення;

2) сприйняття та розпізнавання всіх сигналів зовнішнього світу;

3) потужна теоретична база та самопідготовка;

4) стратегічне мислення, здатність заздалегідь проробляти та прогнозувати різні варіанти;

5) здатність до дедукції та індукції, аналізу та синтезу;

6) здатність моделювати хід думок опонента;

7) здатність ефективно працювати в умовах невизначеності та вірогідності;

8) використання доступної інформації у найбільш доцільний та оптимальний спосіб тощо [13].

Визначення поняття штучного інтелекту у науці здійснюється через поділ його на види за критерієм ступеня відтворення когнітивних функцій людини та впливу останньої на процес прийняття рішень чи здійснення певної діяльності.

Так О. А. Баранов запропонував розрізняти такі види штучного інтелекту:

- «Прикладний штучний інтелект» («слабкий штучний інтелект», «вузький штучний інтелект» або «обмежений штучний інтелект») розуміється як сукупність комп'ютерних програм, які максимально наближено імітують одну або кілька когнітивних функцій людини і використовуються у процесі здійснення конкретної діяльності без участі людини для досягнення поставлених цілей відповідно до заздалегідь визначених критеріїв і параметрів;

- «Загальний штучний інтелект» (або «сильний штучний інтелект») - сукупність комп'ютерних програм, які еквівалентно імітують безліч когнітивних функцій людини та використовуються для здійснення будь-якого виду діяльності без участі людини для досягнення поставлених цілей з певними критеріями і параметрами; 
- «Штучний супер-інтелект» - це сукупність комп'ютерних програм, що імітують повну множину когнітивних функцій людини, додаючи свідомість, суб'єктивні переживання, почуття гідності, поваги, краси тощо, які значно перевищують людські інтелектуальні показники, що дає змогу здійснювати будь-яку діяльність без участі людини для досягнення самостійно визначених цілей за самостійно визначеними критеріями та параметрами [14, с. 19].

Також окремі науковці виділяються такі види штучного інтелекту: слабкий (Weak Artificial Intelligence, WAI), сильний (Strong artificial intelligence, ASI) та штучний суперінтелект (Artificial Superintelligence, ASI), під яким розуміється інтелект, який набагато розумніший, ніж кращий людський інтелект, практично в кожній сфері, включаючи наукову творчість, загальну мудрість і соціальні навички. Також пропонується класифікація роботів: простий робот (simple robot), роботандроїд (robot android), андроїд (android) [14, c. 21-22].

Активне використання штучного інтелекту спостерігаємо у галузі робототехніки. О. А. Баранов вважає робота із штучним інтелектом нерівноправним актором (діючим суб'єктом, який вчиняє дії, що спрямовані на інших), а лише правовим еквівалентом фізичній (або юридичній) особі як суб'єкта правовідносин, тобто фактично лише правовим сурогатом [15, с. 78].

Варто погодитися зі вченими, які розмежовують терміни «робот», «комп'ютерні програми», «інформаційні технології», «штучний інтелект» тощо.

Так, слушним $є$ висновок М. Стефанчука щодо неможливості ототожнення понять «робот» i «штучний інтелект», які співвідносяться між собою як форма та зміст. Штучний інтелект це моделювання здатності до абстрактної, творчої думки (особливо здатності до навчання) за допомогою цифрової комп'ютерної логіки. Натомість робот $є$ пристроєм, машиною, основною здатністю якої $\epsilon$ автоматизоване виконання одного чи декількох завдань за зразком дій людини, якій властиві ознаки рухливості, сенситивності, аналітичності тощо. Саме штучний інтелект надає роботу тих властивостей, якими прийнято його характеризувати, а саме: розумності, здатності до аналізу та обробки інформації, а також до виконання завдань, на які він запрограмований $[16$, с. 6$]$. 
Таким чином, «штучний інтелект» $\epsilon$ досить широким поняттям, принципи, види, ознаки та правила використання якого необхідно закріпити на національному та міжнародному рівнях.

\section{2. Правовий режим штучного інтелекту}

Стрімкий розвиток науки і техніки призвів до появи та активного використання робототехніки, наділеної штучним інтелектом, у всіх сферах життя людини.

Усе це зумовило необхідність розробки етичних принципів для їх проектувальників, виробників та користувачів. Ці принципи містять такі положення:

1) роботи - це багатоцільові інструменти, тому вони не повинні розроблятися тільки або насамперед для знищення чи нанесення шкоди людям, за винятком інтересів національної безпеки;

2) люди, а не роботи, є суб'єктами, що несуть відповідальність. Роботи мають бути спроєктовані так, щоб, наскільки це практично можливо, забезпечити дотримання законів, основних прав і свобод людей, у т. ч. конфіденційності;

3) роботи - це продукція (вироби), і тому їх потрібно спроєктувати та виготовити таким чином, щоб забезпечити їх безпеку і захист;

4) роботи - це предмет матеріального світу. Вони не призначені для використання вразливості користувачів, не мають викликати емоційний відгук або залежність, їх технічний характер має бути очевидний;

5) робота завжди можна співвідносити з особою, яка несе юридичну відповідальність за нього [17].

Окрім принципів використання штучного інтелекту та роботів у повсякденному житті, відкритим залишається питання стосовно визначення правового режиму та місця штучного інтелекту у цивільно-правових відносинах.

Для початку звернемося до доктринального розуміння поняття «правовий режим». Як відомо, останній врегульовує суспільні відносини шляхом обмеження або збільшення обсягу правосуб'єктності, кількості об'єктів права та встановлення особливого механізму правового регулювання [18, с. 30-31].

Окрім елементів механізму правового регулювання (норми права, юридичних фактів, правовідносин, актів реалізації прав та 
обов'язків, правозастосування), у межах яких здійснюється правовий режим, структура останнього містить такі складові як суб'єкт та його правовий статус, об'єкт, методи взаємодії конкретних видів суб'єктів із об'єктами та система гарантій (насамперед юридична відповідальність за порушення режиму) $[18$, c. 31].

Фізична особа як суб'єкт цивільних прав наділена правоздатністю, дієздатністю та деліктоздатністю (правосуб'єктністю) для участі у цивільних правовідносинах.

Правосуб'єктність, якою наділена фізична особа, є особливою. Так, правоздатність - це абстрактна можливість мати цивільні права, яка належить особі з народження та $\epsilon$ невідчужуваною [19]. Водночас дієздатність - це здатність фізичної особи своїми діями набувати цивільні права та обов'язки [20, с. 92]. Вона диференціюється залежно від інтелектуальних та психічних чинників, пов'язаних із віковими особливостями. Однією із рис правосуб'єктності фізичної особи $€$ їі здатність нести відповідальність за свої дії [21, с. 159].

Окрім того, фізична особа відповідальна за дії осіб, якими вона зобов'язана опікуватися або піклуватися відповідно до закону, договору або рішення суду, а також за випадки завдання шкоди іншим особам шляхом експлуатації або належності особі живих тварин чи певних предметів (наприклад завдання шкоди транспортним засобом, собакою бійцівської породи, або іншою твариною чи іншим майновим об'єктом). У цьому разі мова йде мова про об'єкти, які є джерелом підвищеної небезпеки [22].

Натомість юридична особа - це організація, створена та зареєстрована у передбаченому законом порядку, наділена правоздатністю та дієздатністю, може бути позивачем та відповідачем у суді. Згідно з теорією фікції, яка розкриває сутність юридичної особи, остання має власну волю, виражену в рішеннях її органів управління [23, с. 42].

Об'єктами цивільних прав $є$ речі, майно, майнові права, підприємство як майновий комплекс, товари, послуги, роботи, результати інтелектуальної та творчої діяльності, щодо яких можуть виникати цивільні права та обов'язки. Вони можуть бути об'єктом права власності або виступати предметом договорів. Живі істоти, наприклад тварини, теж можуть бути об'єктом цивільних прав через можливість їх відчуження [24, с. 75]. 
Водночас об'єкти цивільних прав ніколи не можуть бути носіями прав та обов'язків. Через це у них немає правосуб'єктності і до них застосовується поняття «правовий режим», який передбачає можливість їх оборотоздатності в цивільному обороті. Об'єкти цивільних прав не мають власної волі; їх фактичну і юридичну долю вирішують фізичні або юридичні особи, що є їх власниками або мають певні майнові права щодо них.

Щодо правового статусу розумних роботів, розроблених на основі використання штучного інтелекту, то відповідно до положень Резолюції Європейського Парламенту 2015/2103(INL), вони $\epsilon$ «електронними особами» [25]. Надання ж статусу особи штучному інтелекту $є$ надзвичайно складним питанням, оскільки тут існують як правові, так і моральні перепони, яких, наприклад, немає при визначенні правового статусу фізичної чи юридичної особи.

Розглянувши думки науковців щодо перспектив правового регулювання використання штучного інтелекту, можна констатувати наявність трьох основних гіпотез, відповідно до яких: роботи є об'єктом суспільних відносин, а значить і об'єктом правовідносин; роботи є суб'єктом суспільних відносин, а значить можуть бути суб'єктом правовідносин; роботи можуть бути як об'єктом, так і суб'єктом суспільних відносин, а значить можуть бути як об'єктом, так і суб'єктом правовідносин [26, с. 22]. Багато вчених, наприклад, М. В. Карчевський, припускають, що в недалекому майбутньому системи (роботи) 3 штучним інтелектом можуть бути суб'єктом правових відносин [27, с. 100].

Підставами для формулювання перших двох гіпотез $є$ такі наукові погляди на роль роботів в суспільних відносинах:

1. Роботи, створені за допомогою штучного інтелекту, сприяють у реалізації суспільних відносин, в яких суб'єктами традиційно виступають юридичні і фізичні особи.

2. Роботи-андроїди можуть виступати «стороною» у правовідносинах, в яких інша стороною $є$ юридичні і фізичні особи. Вони здатні оцінювати дії інших суб'єктів і залежно від результатів цієї оцінки можуть самостійно формувати або змінювати мету та зміст своїх дій. У цьому випадку роботи розглядаються в якості людиноподібних суб'єктів, які вчиняють певні дії у процесі взаємодії із традиційними суб'єктами. I якщо дії останніх у таких відносинах підлягають правовому 
регулюванню, то логічно припустити, що інша сторона також $€$ суб'єктом цих правовідносин.

Професор О. Баранов стверджує, що у цьому контексті необхідно буде вирішити низку питань, пов'язаних 3 тією обставиною, що людина $\epsilon$ біологічною істотою, а робот - ні. Перш за все, це проблема визначення понять, критеріїв, змісту та обсягів правоздатності, дієздатності і деліктоздатності останнього, встановлення спеціальної або загальної правосуб'єктності та багато інших [28, с. 97].

На нашу ж думку, робот виступає не суб'єктом, а об'єктом правовідносин, а повну відповідальність за його дії несе власник або особа, яка ним керує. Відповідно до ст. 177 Цивільний кодекс України (далі - ЦК України) [22] «об'єктами цивільних прав $є$ речі, у тому числі гроші та цінні папери, інше майно, майнові права, результати робіт, послуги, результати інтелектуальної, творчої діяльності, інформація, а також інші матеріальні і нематеріальні блага».

I, якщо ми робимо висновок, що штучний інтелект є об'єктом цивільних правовідносин, то постає логічне питання, чи можливо його віднести до якоїсь з існуючих в ЦК України категорії об'єктів, чи необхідно доповнювати цю статтю новим об'єктом права. Т. Каткова [29] із цього приводу зазначає: «Якщо товариство експертів та законодавці дійдуть висновку, що робот може виступати виключно в якості об'єкта, фактично його роль може бути прирівняна до майна в розумінні статті 177 ЦК України». Ми ж вважаємо, що у цьому випадку необхідно враховувати той факт, що роботи здатні до навчання, узагальнення і проведення аналогій, а також до вирішення складних завдань, чого не можуть інші неживі предмети, тому необхідно розширити список об'єктів, наданий у ст. 177 ЦК України.

Наша точка зору підтверджується і Резолюцією Європейського Парламенту 2015/2103(INL), в якій пропонується присвоїти окремим категоріям роботів індивідуальний реєстраційний номер, який заноситиметься до спеціального реєстру, де можна буде знайти детальну інформацію про робота, включаючи дані про виробника, власника й умови виплати компенсації у разі спричинення шкоди. 


\section{Висновки}

Штучний інтелект $€$ продуктом науково-технологічного прогресу, який покликаний значною мірою полегшити наше життя у різних сферах діяльності. Ця технологія дає змогу машинам виконувати різнопланові завдання, які тривалий час були під силу лише людині, допомагаючи тим самим оптимізувати витрати та зекономити ресурси. Активне використання штучного інтелекту зумовлює необхідність визначення його поняття, ознак та видів, а також правового статусу.

Штучний інтелект - наука та технологія створення інтелектуальних машин (програмних комплексів), здатних брати на себе окремі функції інтелектуальної діяльності людини (наприклад, вибирати та приймати оптимальні рішення на основі раніше отриманого досвіду і раціонального аналізу зовнішніх впливів). Його видами є: прикладний штучний інтелект, загальний штучний інтелект, штучний супер-інтелект. До ознак штучного інтелекту наковці відносять: 1) здатність до комплексної обробки значних обсягів інформації, здобутої 3 різних джерел; 2) здатність до самонавчання (в тому числі, накопичування досвіду, узагальнення, відшукування неочевидних зв'язків) та умовиводів; 3) вміння планувати; 4) здатність до роздумів.

На сьогодні в українському законодавстві не надано ані нормативного визначення цього явища, ані його характеристик. Щодо питання визначення правосуб'єктності штучного інтелекту загалом та роботів зокрема, то тут науковці різних країн ще також не дійшли єдиної думки: одні вважають роботів суб'єктами правовідносин, інші - їх об'єктами, треті доводять, що людиноподібні машини можуть виступати як у ролі суб'єктів, так i об'єктів. На нашу ж думку, роботи є саме об'єктами правовідносин, що підтверджується аналізом Резолюції Європейського Парламенту 2015/2103(INL), а також низки праць українських та зарубіжних вчених. Втім, це питання потребує подальшого грунтовного вивчення та дослідження.

\section{Література:}

1. Єфремов М. Штучний інтелект, історія та перспективи розвитку. Вісник ЖДТУ. № 2(45). 2006. С. 123-127.

2. Эндрю А. Искусственный интеллект. Пер. с англ. М., 1985 р. C. 230 . 
3. Глибовець М.М., Олецький О. В., «Штучний інтелект», К. 2002p. С. 266.

4. Матвійчук А.К. Можливості та перспективи створення штучного інтелекту. Вісник НАН України. 2011. № 12. С. 36 - 51.

5. Проблема искусственного интеллекта в науке и философии. Веб-сайт: URL: http://filnauk.ru/kandidatskijminimum-po-filosofii-nauki/57-problema-iskusstvennogo-intellektav-nauke-i-filosofii.html.

6. История искусственного интеллекта. Веб-сайт: URL: http://www.aiportal.ru/articles/introduction/history-ai.html.

7. Карпенко В. Гіпотетичне майбутнє універсального штучного інтелекту. Філософія науки: традиції на іновації. Сум. держ. пед. ун-т ім. А.С. Макаренко. Суми, 2011 р. № 1(3). С. 57-64.

8. Швирков О. Феномен штучних інтелектуальних систем: філософський погляд. Мультиверсум. Філософський альманах: Зб. наук. праць. Вип. 47. К.: Український центр культури, 2005. C. 193-201.

9. Радутний О. Е. Прогнозно-правовий погляд на штучний інтелект та цифрову людину. URL: https://ivpz.kh.ua/uk/ \%D1\%87\%D0\%B8-\%D0\%BD\%D0\%B0-\%D1\%87\%D0\%B0\%D1\% 81\%D1\%96\%D0\%B2\%D0\%B8\%D0\%B7\%D0\%BD\%D0\%B0\%D0\%B D\%D0\%BD\%D1\%8F-\%D1\%88\%D1\%82\%D1\%83\%D1\%8 7 \% D $0 \%$ B D \% D $0 \%$ B E \% D $0 \%$ B $3 \%$ D $0 \%$ B E - \% D $1 \% 96 \%$ D $0 \%$ B D \% D 1 \% 82 \%D0\%B5\%D0\%BB\%D0\%B5\%D0\%BA\%D1\%82/.

10.Slyusar, Vadym (2019). Artificial intelligence as the basis of future control networks. Coordination problems of military technical and devensive industrial policy in Ukraine. Weapons and military equipment development perspectives/VII International Scientific and Practical Conference. Abstracts of reports. October 8-10, 2019. Kyiv. Pp. 76-77.

11. Методи та системи штучного інтелекту : навч. посіб. Укл. Д.В. Лубко, С.В. Шаров. Мелітополь : ФОП Однорог Т.В., 2019. $264 \mathrm{c}$.

12. Barrat James. Our Final Invention: Artificial Intelligence and the End of Human Era. - URL: http://www.tor.com/2013/09/20/ourfinal-invention-excerpt.

13.Иллюзия восприятия: ограниченность зрения, слуха и других органов чувств человека. Веб-сайт: URL: http://bp21.livejournal.com/103392.html. 
14.Баранов 0. А. Інтернет Речей і штучний інтелект: витоки правового регулювання. IT-право: проблеми та перспективи розвитку в Україні: зб. матеріалів II Міжнар. наук.-практ. конф. (Львів, 17 листоп. 2017 р.). Львів: НУ «Львівська політехніка», 2017. С. $18-42$.

15.Баранов O. А. Інтернет речей (IоT): робот зі штучним інтелектом у правовідносинах. Юридична Україна. 2018. № 5-6. C. 75-95.

16.Стефанчук М.О. Теоретичні засади цивільної правосуб'єктності фізичних осіб та особливості її здійснення : автореф. дис. ... докт. юрид. наук: 12.00.03. Київ, 2020. С. 6.

17.Principles for designers, builders and users of robots. URL: https://epsrc.ukri.org/research/ourportfolio/themes/engineering/ac tivities/principlesofrobotics/.

18.Коссе Д. Д. Правовий режим та механізм правового регулювання: ознаки та співвідношення. Держава і право. 2009. Вип. 44. С. 25-31.

19.Надьон В. В. Деякі аспекти визначення правоздатності в цивільному праві. Теорія $і$ практика правознавства. 2014. Вип. 1 (5). URL : http://dspace.nlu.edu.ua/bitstream/123456789/ 16361/1/5.pdf.

20.Волкова Н. В. Щодо визначення підстав обмеження цивільної дієздатності фізичної особи при розгляді справ у цивільному судочинстві. Часопис цивілістики. 2015. Вип. 18. C. 91-94. URL : http://dspace.onua.edu.ua/bitstream/handle/11300/ 8314/Chasopys\%209194.pdf.pdf?sequence=1\&isAllowed=y.

21.Гринько С. Д. Деліктоздатність неповнолітніх фізичних осіб за цивільним законодавством України та зарубіжних країн: порівняльно-правовий аналіз. Часопис цивілістики. 2015. Вип. 19. C. 158-165. URL: http://dspace.onua.edu.ua/bitstream/handle/ $11300 / 8517 / 33$.pdf.pdf?sequence=1\&isAllowed=y.

22.Цивільний кодекс України. Відомості Верховної Ради України. 2003. №№ 40-44. URL : https://zakon.rada.gov.ua/laws/ show/435-15.

23.Прилуцький Р. Б. Основні теорії юридичної особи та їх вплив на розвиток організаційних форм суб'єктів господарювання. Юридична наука. 2013. № 3. С. 35-49. URL : http://www.irbis-nbuv.gov.ua/cgi-bin/irbis_nbuv/cgiirbis_64.exe? I21DBN=LINK\&P21DBN=UJRN\&Z21ID =\&S21REF=10\&S21CNR=20\&S 
21STN=1\&S21FMT=ASP_meta\&C21COM=S\&2_S21P03=FILA=\&2_S21 STR=jnn_2013_3_6.

24.Спектор О. М. Тварина як особливий об'єкт речових прав. Прикарпатський юридичний вісник. 2015. Випуск 3(9). С. 70-76. URL: http://www.pjv.nuoua.od.ua/v3_2015/15.pdf.

25. European Parliament resolution of 12 February 2019 on a comprehensive European industrial policy on artificial intelligence and robotics (2018/2088(INI)). URL : http://www.europarl.europa.eu/ doceo/document/TA8-2019-0081_EN.html.

26.Баранов, О. А. Правові аспекти національних стратегій розвитку штучного інтелекту. Юридична Україна, (7), 2019 р. C. 21-38.

27. Карчевський, М. В. Правове регулювання соціалізації штучного інтелекту. Вісник Луганського держ. ун-ту внутр. справ ім. Е. О. Дідоренка, (2), 2017 р. С. 99-108.

28.Баранов, 0. А. Інтернет речей як правовий термін. Юридична Україна, (5-6), 2016 р. С. 96-103.

29. Каткова Т. Г. Закони про роботів: сучасний стан i перспективи розвитку. IT право: проблеми і перспективи розвитку в Україні: матеріали наук.-практичної конференції (Львів, 17 листопада 2017 року). Львів: НУ «Львівська політехніка», 2017. C. 58-64. URL: http://aphd.ua/publication-345/. 